\title{
Yield Performance of Okra (Abelmoschus esculentus L. Moench) and Maize (Zea mays L.) as Affected by Time of Planting Maize in Makurdi, Nigeria
}

\author{
M. O. Ijoyah and D. M. Dzer \\ Department of Crop Production, University of Agriculture, PMB 2373, Makurdi, Nigeria \\ Correspondence should be addressed to M. O. Ijoyah, mikejoy2005@yahoo.com
}

Received 3 April 2012; Accepted 13 May 2012

Academic Editors: G. M. Dal Bello and H. Zhang

Copyright ( $) 2012$ M. O. Ijoyah and D. M. Dzer. This is an open access article distributed under the Creative Commons Attribution License, which permits unrestricted use, distribution, and reproduction in any medium, provided the original work is properly cited.

Field experiments were conducted from June to October during 2010 and 2011 cropping seasons at the Research Farm, University of Agriculture, Makurdi, Nigeria, to evaluate the yield performance of okra-maize mixture as affected by time of planting maize. The experiment consisted of three maize planting dates (maize planted at the same time as okra in mid-June, maize planted 2 and 4 weeks later, respectively, in late June and early July) to okra plots. Monocropped okra and maize constituted the control plots. The five treatments were replicated four times in a randomized complete block design. The results obtained showed that the greatest intercrop yield of okra was obtained when maize was planted 4 weeks later (in early July), while the greatest intercrop yield of maize was produced when planted at the same time as okra in mid-June. Planting okra and maize at the same time in mid-June not only recorded the lowest competitive pressure, but also gave the highest land equivalent ratio (LER) values of 1.78 and 1.75, respectively, in years 2010 and 2011, indicating that greater productivity per unit area was achieved by growing the two crops together than by growing them separately. With these LER values, $43.8 \%$ and $42.9 \%$ of land were saved, respectively, in 2010 and 2011. Both crops were found most suitable in mixture when planting was done at the same time in mid-June. This should be recommended for Makurdi location, Nigeria.

\section{Introduction}

In Nigeria, based on the area cropped and quantity produced, maize was the country's third most important cereal crop following sorghum and millet $[1,2]$. It is used mainly for human food and livestock feed. In the industry, it is also very important in the production of starch, oil, and alcohol [3].

Okra (Abelmoschus esculentus L. Moench) was domesticated in West and Central Africa, but is now widely cultivated throughout the tropics primarily for local consumption $[4,5]$. In Nigeria, it ranks third in terms of consumption and production area following tomato and pepper [6]. The immature pods are used as boiled vegetable while in dried form it is used as soup thickener [7]. The green pods are rich sources of vitamins, calcium, potassium, and other minerals [8]. The intercropping of crops by smallholder and peasant farmers has been a common practice throughout the years
[9]. This practice may allow complementary interactions in crops that have greater system resilience [10], reduce insect pest incidence [11] and deliver environmental benefits such as greater soil and water conservation potential [12]. Over $75 \%$ of maize and $60 \%$ of okra grown in Nigeria are produced under intercropping system $[13,14]$.

The response of sole maize and sole okra to varying sowing dates has been studied $[15,16]$. Previous studies in the zone have also addressed various factors that influence the performance of maize and okra in mixture, such as the response of the crops under intercropping to varying population densities and spatial arrangements [17-20]. However, there is a dearth of information on the yield performance of intercropped maize and okra as affected by time of planting maize, as well as assessing the advantages of the intercropping system. This study was designed to augment the currently available information. 
TABLE 1: Meteorological information for Makurdi (June-October) 2010, 2011.

\begin{tabular}{|c|c|c|c|c|c|}
\hline \multirow{2}{*}{ Year/month } & \multirow{2}{*}{$\begin{array}{l}\text { Average monthly } \\
\text { rainfall }(\mathrm{mm})\end{array}$} & \multicolumn{2}{|c|}{ Average monthly temperature $\left({ }^{\circ} \mathrm{C}\right)$} & \multirow{2}{*}{$\begin{array}{l}\text { Mean daily radiation } \\
\qquad\left(\mathrm{MJ} \mathrm{m}^{-2} \mathrm{~d}^{-1}\right)\end{array}$} & \multirow{2}{*}{$\begin{array}{c}\text { Average relative } \\
\text { humidity }(\%)\end{array}$} \\
\hline & & Max. & Min. & & \\
\hline \multicolumn{6}{|l|}{2010} \\
\hline June & $237.0(21)^{+}$ & 30.6 & 22.3 & 7.29 & 76.2 \\
\hline July & $235.2(20)$ & 30.7 & 22.7 & 7.11 & 76.8 \\
\hline August & $225.0(15)$ & 30.5 & 23.1 & 7.32 & 77.4 \\
\hline September & $210.0(12)$ & 31.4 & 21.2 & 6.78 & 77.8 \\
\hline October & $110.3(7)$ & 32.4 & 23.3 & 6.96 & 75.2 \\
\hline \multicolumn{6}{|l|}{2011} \\
\hline June & $230.0(18)^{+}$ & 31.2 & 21.0 & 7.11 & 76.4 \\
\hline July & $228.4(16)$ & 30.7 & 21.3 & 7.25 & 75.8 \\
\hline August & $215.0(14)$ & 30.3 & 23.0 & 6.99 & 79.6 \\
\hline September & $198.2(11)$ & 30.0 & 22.3 & 6.86 & 78.0 \\
\hline October & $96.0(7)$ & 30.5 & 21.0 & 6.90 & 75.2 \\
\hline
\end{tabular}

${ }^{+}$Values in parenthesis indicate number of rainy days. Source: Air Force Base, Makurdi Meteorological Station.

\section{Materials and Methods}

2.1. Site Description. The experiments were conducted from June to October, 2010 and 2011 cropping seasons at the Research Farm of the University of Agriculture, Makurdi, Nigeria, to evaluate the yield performance of okra-maize mixture as affected by time of planting maize. The study location $\left(7^{\circ} 44^{\prime} \mathrm{N}, 8^{\circ} 35^{\prime} \mathrm{E}\right)$ and at an altitude of $228 \mathrm{~m}$ above sea level falls within the Southern Guinea savanna agroecological zone of Nigeria. The meteorological information of the area over the trial period is provided in Table 1. The average monthly temperature over the years ranged from $21.0^{\circ} \mathrm{C}$ to $32.4^{\circ} \mathrm{C}$, while the average relative humidity ranged from $75.2 \%$ to $79.6 \%$. Mean daily radiation was low throughout the growth period. The month of June recorded the highest amount of rainfall and highest number of rainy days.

2.2. Variety, Planting, Treatments, and Experimental Design. The variety of okra used was "Lady Finger" while that of maize was "Oba 98" (an open pollinated variety). Both are popular varieties grown by farmers and show good adaptation to the local environment.

The experimental area $\left(229.5 \mathrm{~m}^{2}\right)$ which consisted of sandy-loam soil was ploughed, harrowed, ridged, and divided into 20 plots. Each plot had an area of $9 \mathrm{~m}^{2}$. The plots consisted of 3 ridges in which 10 okra plants per ridge were planted at a spacing of $100 \mathrm{~cm} \times 30 \mathrm{~cm}$, giving a total plant population of 30 okra plants per plot $(33,333$ okra plants per hectare equivalent). Okra seeds were planted about 2$3 \mathrm{~cm}$ deep in a single row on top of the ridges. Maize was planted at the same time as okra in mid-June (OM), two weeks later in late June $(\mathrm{OM}+2)$, and four weeks later in early July $(\mathrm{OM}+4)$. Sole maize and sole okra planted in mid-June constituted the control treatments. Maize was spaced $30 \mathrm{~cm}$ apart in single row on top of the ridges and in between okra plants to give a plant population of 30 maize stands per plot (33,333 maize plants per hectare equivalent). Three maize seeds were planted per position, which were later thinned to one plant per position at six days after planting. The three maize planting dates to okra and the planting of okra and maize as sole crops constituted the treatments. The five treatments were laid out in a randomized complete block design (RCBD) with four replications.

2.3. Cultural Practices. The recommended rate of compound fertilizer NPK (15:15:15) for sole maize: $100 \mathrm{~kg} \mathrm{Nha}^{-1}$, $40 \mathrm{~kg} \mathrm{Pha}^{-1}$, and $60 \mathrm{~kg} \mathrm{Kha}^{-1}$; for sole okra: mixed fertilizer NPK $(15: 15: 15)$ at the rate of $100 \mathrm{~kg} \mathrm{ha}^{-1}$ and for okra-maize mixture: $100 \mathrm{~kg} \mathrm{Nha}^{-1}, 100 \mathrm{kgPha}^{-1}$ and $100 \mathrm{~kg} \mathrm{~K} \mathrm{ha}{ }^{-1}$ was applied [21]. The row method of fertilizer application was employed. The fertilizer was applied twice to each plot at 3 and 6 weeks after planting (WAP) for the sole crops and the intercrops. Weeding was done using the native hoe as the need arose. The use of native hoe is a typical practice by farmers in the area.

Okra was harvested when the tip of pod was observed to break easily when pressed with the finger tip [22]. Maize was harvested at 12 WAP (weeks after planting), when the leaves turned yellowish and fallen off which were signs of senescence and cob maturity. Entire plots were harvested for yield measurements.

2.4. Data Collection. Data taken for okra include days to $50 \%$ flowering, okra plant height at 50\% flowering (measured as the distance in $\mathrm{cm}$ from the soil surface to the tip of the topmost leaf), number of branches per plant, leaf area at 50\% flowering, pod length $(\mathrm{cm})$, pod diameter $(\mathrm{cm})$, number of pods per plant, pod weight $(\mathrm{g})$, and yield $\left(\mathrm{t} \mathrm{ha}^{-1}\right)$.

Data taken for maize include days to $50 \%$ flowering, maize plant height at $50 \%$ flowering (measured as the distance in $\mathrm{cm}$ from the soil surface to the collar of the top most leaf), number of leaves per plant, number of cobs per plant, cob length $(\mathrm{cm})$, cob diameter (the diameters at the head, centre, and tail ends of the cob were measured in $\mathrm{cm}$ and averaged). The cobs were weighed using an electronic weighing balance to obtain cob weight $(\mathrm{g})$. The cobs were 


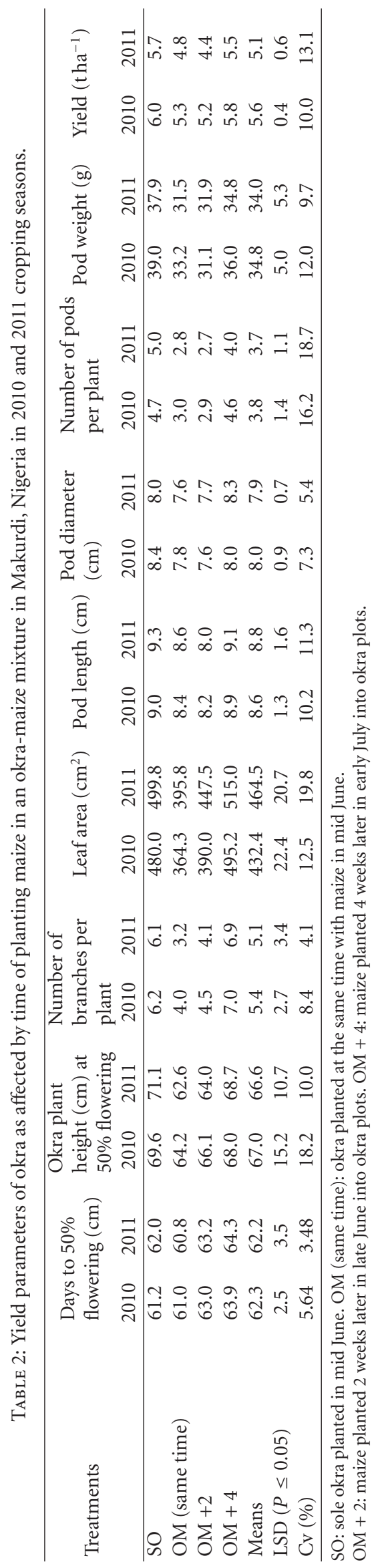




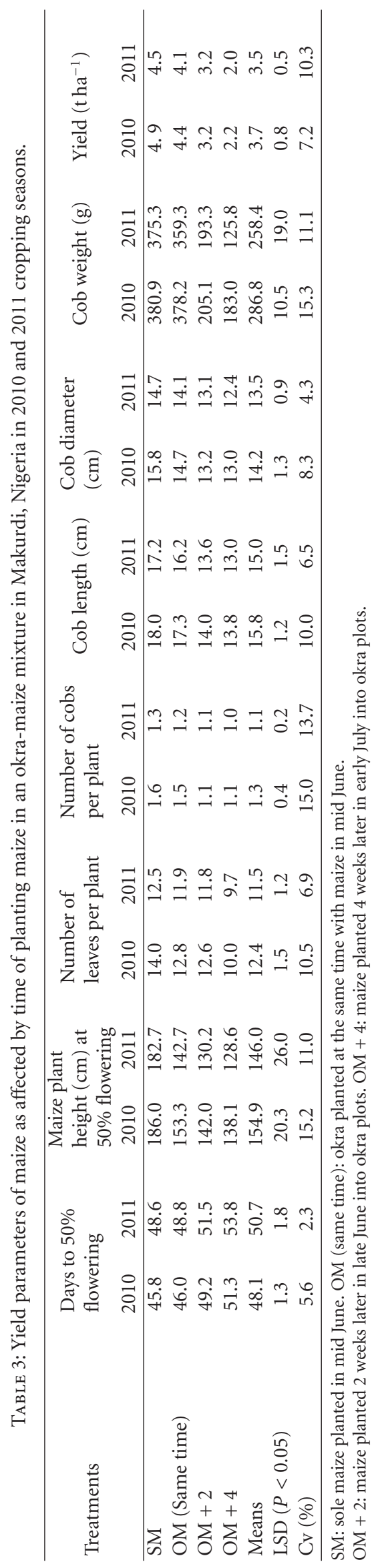


TABLE 4: Land equivalent ratio (LER), competitive ratio (CR), and Percentage (\%) of land saved from intercropping okra and maize planted at different times in 2010 and 2011 cropping seasons.

\begin{tabular}{|c|c|c|c|c|c|c|c|c|c|c|c|c|c|c|c|c|c|c|}
\hline \multirow{3}{*}{ Treatments } & \multicolumn{4}{|c|}{ Sole crop yield $\left(\mathrm{tha}^{-1}\right)$} & \multicolumn{4}{|c|}{ Intercrop yield $\left(\mathrm{tha}^{-1}\right)$} & \multicolumn{8}{|c|}{ Okra-maize mixture } & \multirow{2}{*}{\multicolumn{2}{|c|}{ \% Land saved }} \\
\hline & \multicolumn{2}{|c|}{ Sole okra } & \multicolumn{2}{|c|}{ Sole maize } & \multicolumn{2}{|c|}{ okra } & \multicolumn{2}{|c|}{ maize } & \multicolumn{2}{|c|}{ LER } & \multicolumn{2}{|c|}{ Lo } & \multicolumn{2}{|c|}{$\mathrm{Lm}$} & \multicolumn{2}{|c|}{ CR } & & \\
\hline & 2010 & 2011 & 2010 & 2011 & 2010 & 2011 & 2010 & 2011 & 2010 & 2011 & 2010 & 2011 & 2010 & 2011 & 2010 & 2011 & 2010 & 2011 \\
\hline Soles & 6.0 & 5.7 & 4.9 & 4.5 & - & - & - & - & - & - & - & - & - & - & - & - & - & - \\
\hline OM (same time) & - & - & - & - & 5.3 & 4.8 & 4.4 & 4.1 & 1.78 & 1.75 & 0.88 & 0.84 & 0.90 & 0.91 & 0.98 & 0.92 & 43.8 & 42.9 \\
\hline $\mathrm{OM}+2$ & - & - & - & - & 5.2 & 4.4 & 3.2 & 3.2 & 1.52 & 1.48 & 0.87 & 0.77 & 0.65 & 0.71 & 1.34 & 1.08 & 34.2 & 32.4 \\
\hline $\mathrm{OM}+4$ & - & - & - & - & 5.8 & 5.5 & 2.2 & 2.0 & 1.42 & 1.40 & 0.97 & 0.96 & 0.45 & 0.44 & 2.16 & 2.18 & 29.6 & 28.6 \\
\hline
\end{tabular}

Soles: sole crops of okra and maize planted in mid June. OM (Same time): okra planted at the same time with maize in mid June. $\mathrm{OM}+2$ : maize planted 2 weeks later in late June into okra plots. $\mathrm{OM}+4$ : maize planted 4 weeks later in early July into okra plots. LER $=($ Intercrop yield of crop A/Sole crop yield of Crop A $)+$ (Intercrop yield of crop B/Sole crop yield of Crop B).

Lo, $\mathrm{Lm}=$ Partial LER of component crops.

$\mathrm{CR}=\mathrm{Lo} / \mathrm{Lm}$ (Division of the partial land equivalent ratios of the component crops).

$\%$ land saved $=100-1 /$ LER $\times 100$.

later shelled manually and the total grains for each plot weighed to obtain the yield $\left(\mathrm{tha}^{-1}\right)$.

2.5. Statistical Analysis. All data were statistically treated using the Analysis of Variance (ANOVA) for randomized complete block design and the Least Significant Difference (LSD) was used for mean separation $(P \leq 0.05)$ following the procedure of Steel and Torrie [23]. The land equivalent ratio (LER) was determined as described by Willey [24] using the formula:

$$
\begin{aligned}
\text { LER }= & \frac{\text { Intercrop yield of crop A }}{\text { Sole crop yield of A }} \\
& +\frac{\text { Intercrop yield of crop B }}{\text { Sole crop yield of B }} .
\end{aligned}
$$

The competitive ratio (CR) as described by Willey and Rao [25] was determined using the formula: $\mathrm{CR}=$ $(\mathrm{Lo} / \mathrm{Lm})(\mathrm{Zo} / \mathrm{Zm})$, where Lo is partial LER for okra Lm is partial LER for maize; Zo and Zm are the sown proportion of okra and maize, respectively.

The percentage (\%) land was saved as described by Willey [24] using the formula:

$$
\% \text { Land saved }=100-\frac{1}{\text { LER }} \times 100 .
$$

These calculations were used to determine the productivity of the intercropping system and to assess the compatibility and suitability of the crops for intercropping.

\section{Results and Discussion}

The yield parameters of okra as affected by time of planting maize in an okra-maize mixture in years 2010 and 2011 are given in Table 2. Flowering in okra occurred earliest when sown at the same time as maize, and flowering was delayed by planting maize later. The greater number of days taken to achieve $50 \%$ flowering might have been a result of the inability of okra plants intercropped with maize planted 2 and 4 weeks later to accumulate enough thermal units required to induce early flowering. Maize sown at 2 and
4 WAP okra $(\mathrm{OM}+2$ and $\mathrm{OM}+4)$ might have exerted maximum demand on growth resources, thus prolonging days to attain $50 \%$ flowering for okra. This view agreed with Hugar and Palled [26] who reported that maize has high potential for carbohydrate accumulation per unit area per day. The height of okra planted as a sole crop and that sown in intercrop with maize at different times showed no significant difference.

The largest leaf area and the greatest number of branches per plant for intercropped okra were produced when maize was planted 4 weeks later into the mixture. This might be attributed to greater light interception by okra during the longer days in June before there was competition with the maize crop. This result agreed with the findings of Hossain et al. [27] who found out that number of branches increased as time of sowing okra progressed. This view also agreed with Jiao et al. [28] who reported that when two morphologically dissimilar crops with different periods of maturity are intercropped, light is the vital factor that determines the leaf area.

Although pod length and pod diameter were not significantly $(P \leq 0.05)$ different, the number of pod was greater for sole okra, compared to that obtained from okra plant intercropped with maize sown at different times. Under intercropping, more pods per plant were formed in $\mathrm{OM}+4$ than $\mathrm{OM}+2$ (Table 2). However, there was no difference in pod number between monocropped okra and $\mathrm{OM}+4$. Greater competition for available nutrients and light could have been responsible for the decreased production of pods. Seran and Jeyakumaran [29] reported that the number of pods per capsicum plant was lower in capsicum-vegetable cowpea intercropping compared to monocropping due to competition for light and nutrients.

The greatest pod weight and yield were obtained from sole okra, whereas under intercropping, greatest okra pod weight and yield were obtained with $\mathrm{OM}+4$ (Table 2). The larger okra leaf area produced under $\mathrm{OM}+4$ could have contributed to the greatest pod weight and yield. This agreed with the findings of Ogindo and Walker [30]. Okra yields in $\mathrm{OM}$ were greater than $\mathrm{OM}+4(8.6 \%$ and $12.7 \%$ in 2010 and 2011, resp.), and greater than $\mathrm{OM}+$ $2(10.3 \%$ and $20.0 \%$ in 2010 and 2011, resp.). Yields 
obtained in sole okra and $\mathrm{OM}+4$ showed no significant difference.

The least number of days to attain 50\% flowering was obtained from monocropped maize. Days to 50\% flowering for maize increased as time of planting maize into okra plots advanced (Table 3 ).

The tallest maize height was produced from sole maize, but, under intercropping, maize height decreased as time of planting maize into okra plots advanced (Table 3 ). This view agreed with the findings of Fakorede [31] but contradicted that of Kalu et al. [16] were maize height increased as the year progressed. The conflict in results could be due to different environmental conditions at the study locations and the genetic potential of the maize varieties used. Although not measured here, plant height indicates the yield of stover, which is also important to farmers for a variety of uses.

In both years, the number of leaves per plant, number of cobs per plant, cob length, cob diameter, cob weight were significantly $(P \leq 0.05)$ reduced with later planting of maize into okra (Table 3 ).

Compared with sole maize, yields in $\mathrm{OM}+4$ were decreased by $55 \%$ (in 2010 and 2011) in $\mathrm{OM}+4$, and by $35 \%$ and $29 \%$ (in 2010 and 2011, resp.) in OM +2 (Table 3). This does not agree with Makinde et al. [32] who reported greater yields of sorghum in combination with okra as season advanced. There were no significant differences in yield between sole maize and OM. The greatest intercropped yield of maize was obtained with $\mathrm{OM}$, and yields of $\mathrm{OM}+2$ were greater than $\mathrm{OM}+4$. This result agreed with Unamma [33] who reported that best intercropped maize yield was obtained when planting was done at the same time as cassava in a cassava-maize mixture.

Intercropping okra and maize at the same time in midJune not only recorded the lowest competitive pressure but also gave the highest land equivalent ratio (LER) values of 1.78 and 1.75, respectively, in years 2010 and 2011, indicating that higher productivity per unit area was achieved by growing the two crops together than by growing them separately (Table 4). With these LER values, $43.8 \%$ and $42.9 \%$ of land were saved, respectively, in 2010 and 2011, which could be used for other agricultural purposes. Both crops were found to be complementary and most suitable in mixture when planting was done at the same time in midJune.

\section{Conclusion}

From the results obtained, it can be concluded that it is advantageous to intercrop okra with maize. This is associated with a higher land equivalent ratio values greater than 1.0, indicating greater productivity per unit area, in addition to greater percentage of land saved. While the greatest intercrop yield of okra was obtained when maize was planted four weeks later in early July into the mixture, greatest intercrop yield of maize was produced when okra was planted at the same time in mid-June. It is however recommended that further investigation will be done to evaluate a wider range of okra and maize varieties and across different locations within the Guinea savanna ecological zone of Nigeria.

\section{Acknowledgment}

The authors are grateful to the research technicians of the University of Agriculture Research Farm in Makurdi, for their assistance in the field operations.

\section{References}

[1] P. R. Uzozie, "Effect of time of interplanting maize on the performance of cassava-maize intercrop," Journal of Agricultural Science, vol. 12, pp. 18-21, 2001.

[2] J. E. Iken and N. A. Amusa, "Maize research and production in Nigeria," African Journal of Biotechnology, vol. 3, no. 6, pp. 302-307, 2004.

[3] J. G. Kling and G. Edmeades, "Morphology and growth of maize," Research Guide no. 9, Training Programme, International Institute of Tropical Agriculture (IITA), Ibadan, Nigeria, 1997.

[4] R. R. Schipper, African Indigenous Vegetables: An Overview of the Cultivated Species, Natural Resource Institute. E.U. Technical Centre of Agriculture and Rural Cooperation, Chathan, UK, 2000.

[5] A. Y. Kamara, A. Menkir, S. O. Ajala, and I. Kureh, "Performance of diverse maize genotypes under nitrogen deficiency in the northern Guinea Savanna of Nigeria," Experimental Agriculture, vol. 41, no. 2, pp. 199-212, 2005.

[6] I. K. Ibeawuchi, "Intercropping a food production strategy for resource poor farmers," Nature and Science, vol. 5, no. 1, pp. 46-49, 2007.

[7] S. K. Yadev and B. S. Dhanker, "Performance of 'Varsha Uphar' cultivar of okra as affected by sowing dates and plant geometry," Vegetable Science, vol. 27, pp. 70-74, 2002.

[8] K. Lee, C. Y. Cho, and S. K. Park, "The effect of nitrogen fertilizer, plant density and sowing date on the yield of okra," Korean Journal of Crop Science, vol. 35, no. 8, pp. 179-183, 1990.

[9] M. O. Ijoyah, "Yield effects of intercropping white guinea yam (Dioscoreae rotundata P.) minisetts and maize (Zea mays L.) in the Southern Guinea Savanna of Nigeria," African Journal of Agricultural Research, vol. 6, no. 23, pp. 5227-5231, 2011.

[10] M. S. Wolfe, "Agriculture: crop strength through diversity," Nature, vol. 406, no. 6797, pp. 681-682, 2000.

[11] B. Ramert, "The use of mixed specie cropping to manage pests and diseases. Theory and aparactice, UK Organic Research, 2002," in Proceedings of the COR Conference, Aberystwyth, UK, 2002.

[12] J. E. Gilley, L. V. Kramer, and B. Eghball, "Managing runoff following manure application," Journal of Soil and Water Conservation, vol. 57, no. 6, pp. 530-533, 2002.

[13] J. Ofosu-Anim and N. V. Limbani, "Effect of intercropping on the growth and yield of cucumber (Cucumis sativus L.) and okra (Abelmoschus esculentus L. Moench)," International Journal Agriculture and Biology, vol. 9, no. 4, pp. 594-597, 2007.

[14] M. O. Ijoyah and J. Jimba, "Effects of planting methods, planting dates and intercropping systems on sweet potatookra yields in Makurdi, Nigeria," Agricultural Science Research Journal, vol. 1, no. 8, pp. 184-190, 2011. 
[15] M. O. Ijoyah, S. O. Atanu, and S. Ojo, "Productivity of okra (Abelmoschus esculentus L. Moench) at varying sowing dates in Makurdi, Nigeria," Journal of Applied Biosciences, vol. 32, pp. 2015-2019, 2010.

[16] B. A. Kalu, A. A. Ojo, F. S. Ablorh, and O. O. Agbede, "Yield responses of maize to planting dates under both upland and lowland preparation methods in Benue State, Nigeria," Nigerian Journal of Agronomy, vol. 2, no. 1, pp. 15-20, 1986.

[17] F. O. Olasantan and E. O. Lucas, "Intercropping maize with crops of differing canopy heights and similar or different maturities using different spatial arrangements," Journal of Agriculture Science and Technology, vol. 2, no. 1, pp. 13-22, 1992.

[18] G. O. Kayode and S. U. Remison, "Effect of population density and nitrogen on maize in the Southern Guinea savanna zone of Nigeria," Nigerian Agricultural Journal, vol. 17-18, pp. 22 31, 1982.

[19] M. O. Ijoyah, E. O. Adagba, and T. Iorlamen, "Productivity of okra-maize intercropping system as influenced by varying maize plant densities in Makurdi, Nigeria," International Journal of Current Research, vol. 4, no. 4, pp. 59-63, 2012.

[20] M. O. Ijoyah and J. Jimba, "Evaluation of yield and yield components of Maize (Zea mays L.) and okra (Abelmoschus esculentus L. Moench) intercropping system at Makurdi, Nigeria," Journal of Biodiversity and Environmental Sciences, vol. 2, no. 2, pp. 38-44, 2012.

[21] W. O. E. Enwezor, J. Udo, and K. A. Ajotade, Fertilizer Procurement and Distribution. Fertilizer Use and Management Practice for Crops in Nigeria, Savenda Publishers, Nsukka, Nigeria, 1989.

[22] S. D. Usman, "Seed production and quality of okra as affected by sowing time," Seed Research, vol. 29, no. 1, pp. 47-51, 2001.

[23] R. G. D. Steel and J. H. Torrie, Principles and Procedures of Statistics. A Biometrical Approach, McGraw Hill, New York, NY, USA, 2nd edition, 1980.

[24] R. W. Willey, "Evaluation and presentation of intercropping advantages," Experimental Agriculture, vol. 21, pp. 119-133, 1985.

[25] R. W. Willey and M. R. Rao, "A competitive ratio for quantifying competition between intercrops," Experimental Agriculture, vol. 16, pp. 117-125, 1980.

[26] H. Y. Hugar and Y. B. Palled, "Studies on maize-vegetable intercropping systems," Karnataka Journal of Agricultural Science, vol. 21, pp. 162-164, 2008

[27] M. D. Hossain, M. A. Salam, M. S. Islam, and M. A. T. Masud, "Yield and quality of okra seed as influenced by time of sowing," Bangladesh Journal of Seed Science Technology, vol. 3, no. 1-2, pp. 83-87, 2001.

[28] N. Y. Jiao, C. Zhao, T. Y. Ning et al., "Effects of maizepeanut intercropping on economic yield and light response of photosynthesis," Chinese Journal of Applied Ecology, vol. 19, no. 5, pp. 981-985, 2008.

[29] T. H. Seran and J. Jeyakumaran, "Effect of planting geometry on yield of Capsicum (Capsicum annum L.) intercropping with vegetable cowpea (Vigna unguiculata L.)," Journal of Science, vol. 6, pp. 11-19, 2009.

[30] H. O. Ogindo and S. Walker, "Comparison of measured changes in seasonal soil water content by rainfed maize-bean intercrop and component cropping systems in a semi-arid region of southern Africa," Physics and Chemistry of the Earth, vol. 30, no. 11-16, pp. 799-808, 2005.

[31] M. A. B. Fakorede, "Response of maize to planting dates in a tropical rainforest location," Experimental Agriculture, vol. 21, pp. 19-30, 1985.
[32] A. A. Makinde, N. J. Bello, F.O. Olasantan, and M. A. Adebisi, "Seasonality and crop combination effects on growth and yield of two sorghum (Sorghum bicolor) cultivars in sorghum/maize/okra intercrops in a forest savanna transition zone of Nigeria," Agricultural Journal, vol. 6, no. 3, pp. 92-99, 2011.

[33] R. P. A. Unamma, "Effect of time of interplanting maize on the performance of yam/maize intercrop," Annual Farming Systems Research, Umudike, Nigeria, February 1988. 


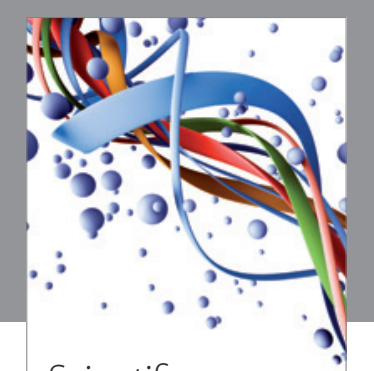

Scientifica
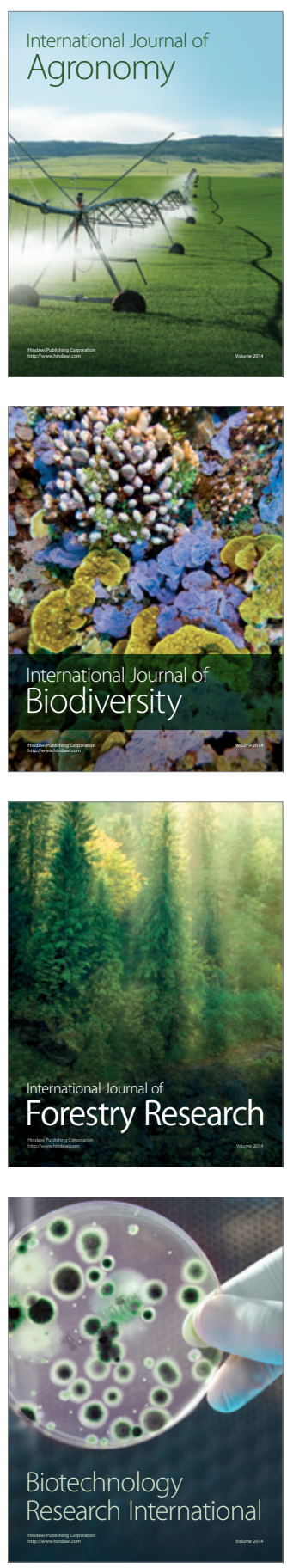
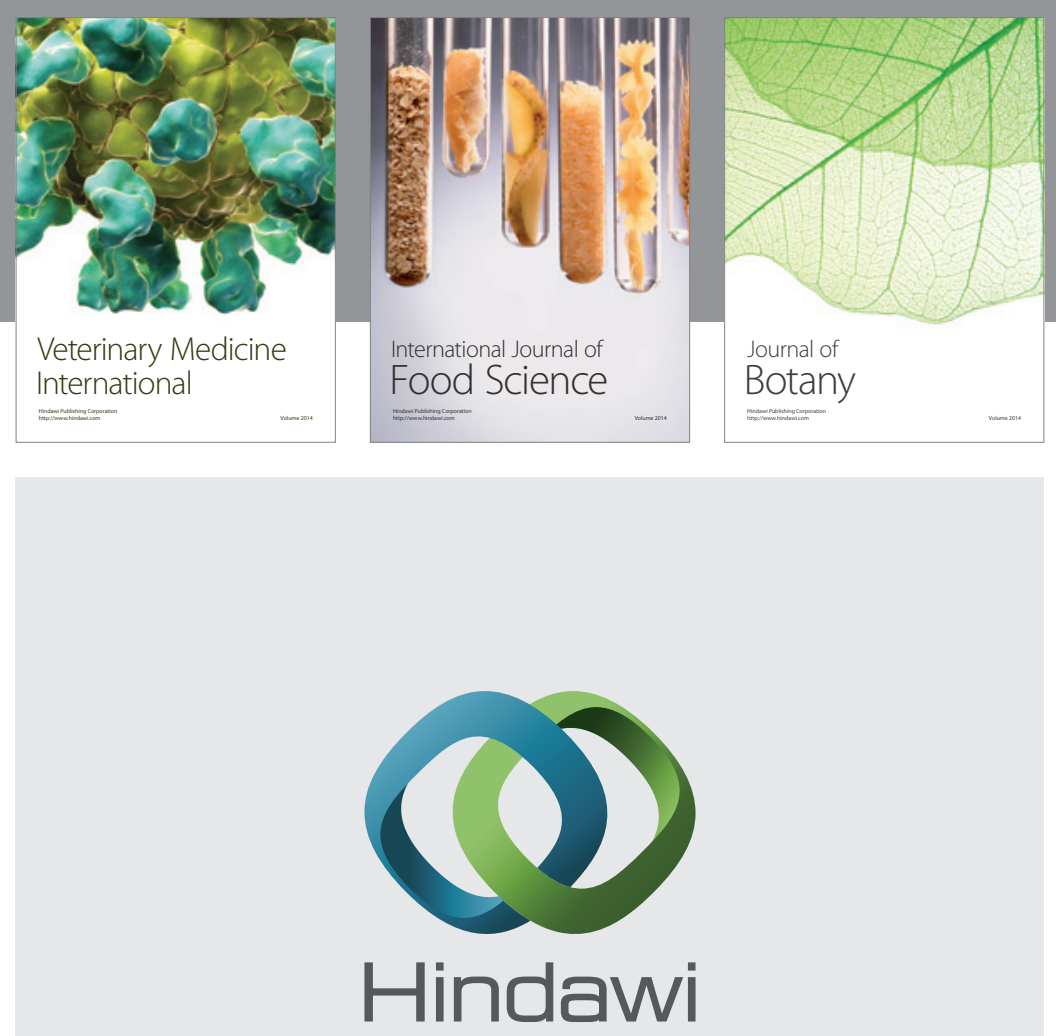

Submit your manuscripts at

http://www.hindawi.com
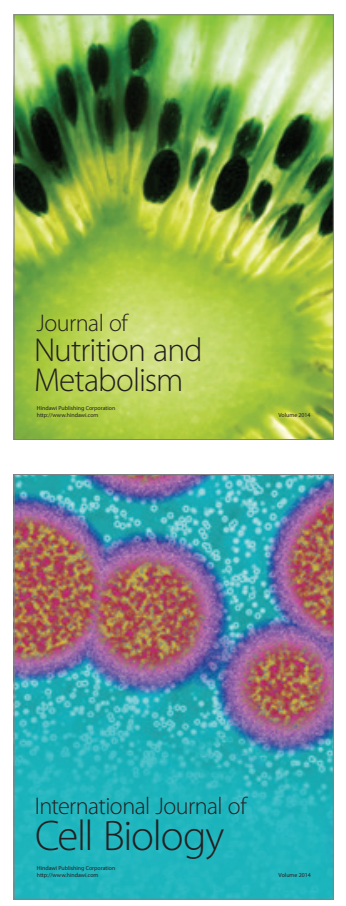
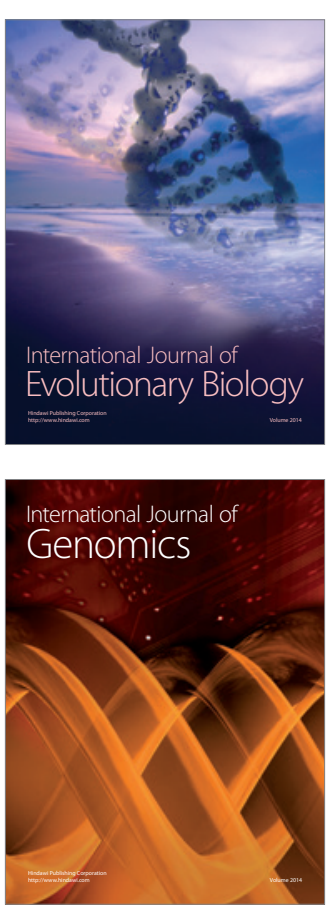
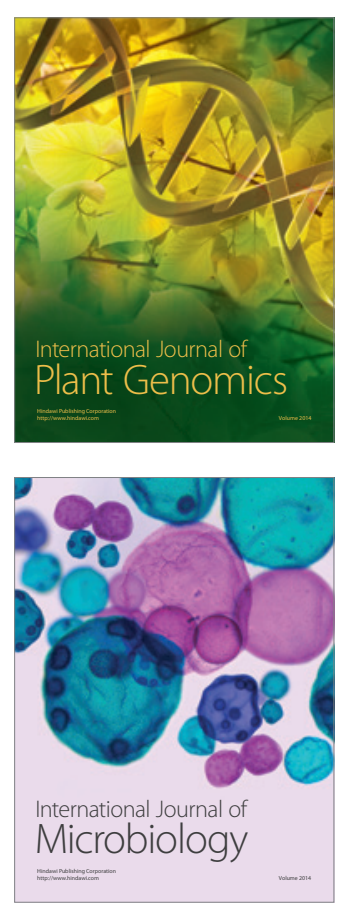

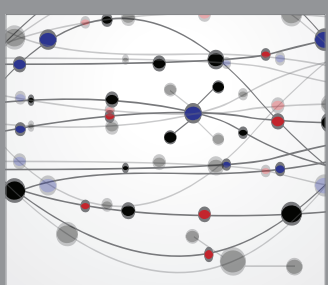

The Scientific World Journal
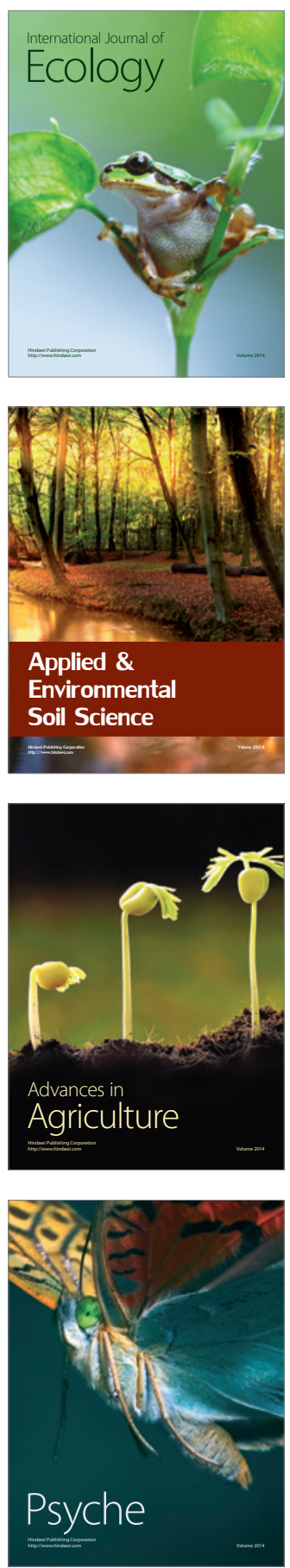